to account for the introduction of $F$. auricularia into this estate in any other way than through the agency of imported plants. Their prodigious increase can also be explained with no less difficulty, for refuse or anything which one might expect to be favorable food is not permitted to accumulate. Not having the time to devote to the subject, I was unable to determine upon what the earwigs were feeding.

It seems quite important that the matter be investigated by economic entomólogists, otherwise, $\boldsymbol{F}$. auricularia might soon rival the familiar and unwelcome Blattella germanica as a household pest.

\title{
A NEW STRATIOMYID
}

By Charles W. Johnson, Boston Society of Natural History.

This interesting fly was taken on one of my many collecting trips to the Berkshire Hills in western Massachusetts. I have delayed recording it, hoping that additional material would be obtained. In the table of genera this would go in the genus Zabrachia Coquillett, but the form of the antennæ would at once exclude it from that genus, while both venation and antennæ bar it from the other genera of the group. Although lacking the anterior branch of the third vein, the position of the second and third veins is nearer that of Pachygaster than of Zabrachia.

\section{Berkshiria gen. nov.}

Third joint of the antennæ oblong, about double the length of the first and second taken together; third joint with five annuli, the basal one broader than the others; arista terminal, style-like, about as long as the entire antenna; front with two longitudinal ridges; transverse suture deeply impressed; scutellum large, rounded, with a broad depressed margin; third longitudinal vein without the anterior branch; ends of the terminal joints of the tarsi with bristle-like hairs. Type B. albistylum sp. nov.

\section{Berkshiria albistylum sp. nov.}

Black; front shining, the two ridges forming deep central and orbital grooves, ocelligerous tubercle prominent; face receding, the orbits white; antenna yellow, arista white with its basal fourth black. Thorax sparsely covered with a whitish pubescence; humeri angulate with a small yellow spot at each point, a raised collar extending between the humeri, and a blunt spine on each side before the base of the 
wing. Abdomen broad, about double the width of the thorax, the five segments shining, sparsely covered with whitish hairs. Halteres white, base of the knobs and stems brown. Legs black, knees, tips of the tibiæ and the tarsi yellow, the last two joints of the latter brownish. Wings hyaline, veins yellowish, three veins extending from the discal cell. Length, $4 \mathrm{~mm}$.

One specimen, collected along Austen's Brook, Chester, Mass., May 28, 1912. Type in the collection of the Boston Society of Natural History.

Other interesting Stratiomyidæ collected at Chester, Mass., are Scoliopelta luteipes Will. (Entom. Amer., I, 154, 1885) which was quite common August 5 and 6, 1914, and a specimen of Chrysochroma nigricornis Loew, July 25, 1913.

\section{A NEW AËDINE.}

By C. S. Ludlow, Army Medical Museum, Washington, D. C.

A long while ago, before it was known that Skusea multiplex Theob. had long palpi in the male, and therefore was not a Skusea, I received and named a lot of mosquitoes, which seemed to be of this species. Nothing had called my attention to the change of position of multiplex, so the specimens were not re-examined, but lately I sent specimens to Mr. Edwards, who has called my attention to this point and, as the species was undescribed, kindly returned the specimens for description. In general appearance the female probably more nearly resembles multiplex than any other species but it is described below as

Aëdes panayensis sp. nov.

Head dark brown, covered with flat brown scales, which appear grey in some lights, and small curved scales around the eyes; antennæ brown, white-banded, verticels brown, pubescence white; palpi brown and very short in both male and female; proboscis brown; clypeus brown; eyes dark brown.

Prothoracic lobes brown; mesothorax brown, sometimes very dark, and covered with slender golden brown curved scales; scutellum as mesothorax, with six long marginal brown bristles on the mid, and three marginal bristles on the lateral lobes; pleura dark, with bunches of white scales; metanotum dark brown.

Abdomen with brown scales and large white basal lateral spots on all but the eighth segment.

Legs: coxæ and trochanters light; femora dorsally brown, and ventrally white nearly to the apex, and a light knee spot; tibiæ dorsally brown, darker than the 

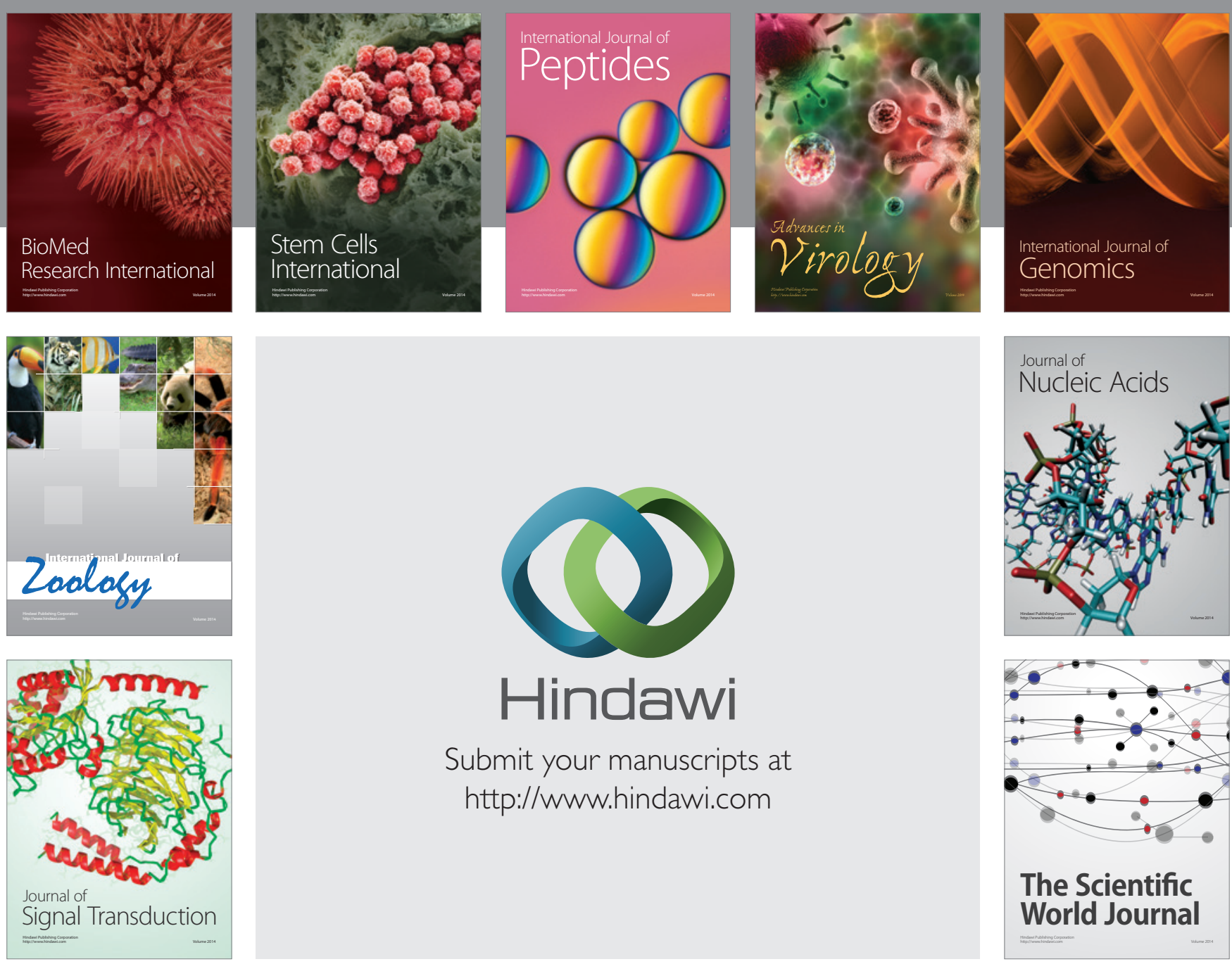

Submit your manuscripts at

http://www.hindawi.com
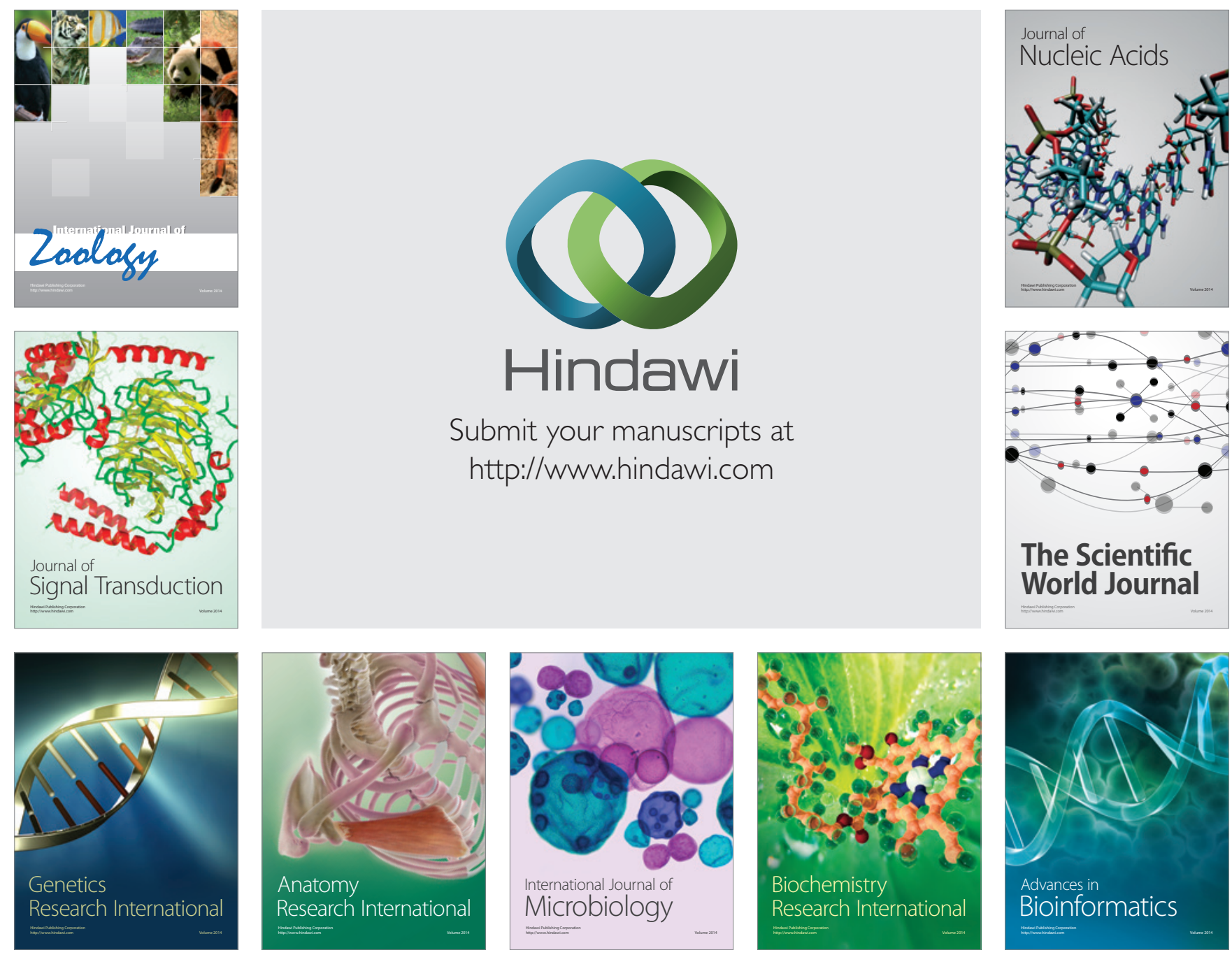

The Scientific World Journal
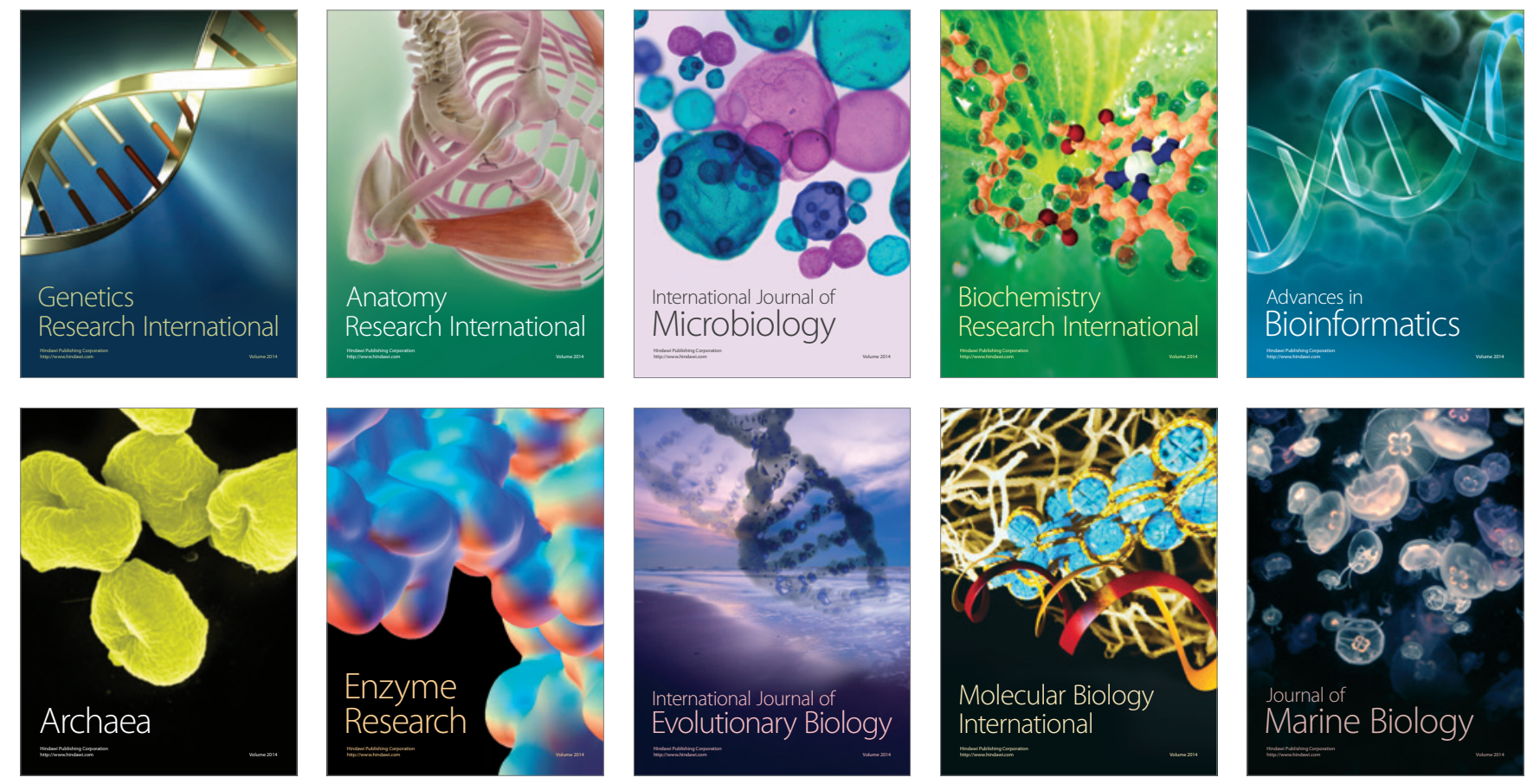